\title{
An eco-efficiency evaluation of community-scale rainwater and stormwater harvesting in Aarhus, Denmark
}

\author{
Faragò, Maria; Brudler, Sarah; Godskesen, Berit; Rygaard, Martin
}

Published in:

Journal of Cleaner Production

Link to article, DOI:

10.1016/j.jclepro.2019.01.265

Publication date:

2019

Document Version

Peer reviewed version

Link back to DTU Orbit

Citation (APA):

Faragò, M., Brudler, S., Godskesen, B., \& Rygaard, M. (2019). An eco-efficiency evaluation of community-scale rainwater and stormwater harvesting in Aarhus, Denmark. Journal of Cleaner Production, 219, 601-612. https://doi.org/10.1016/j.jclepro.2019.01.265

\section{General rights}

Copyright and moral rights for the publications made accessible in the public portal are retained by the authors and/or other copyright owners and it is a condition of accessing publications that users recognise and abide by the legal requirements associated with these rights.

- Users may download and print one copy of any publication from the public portal for the purpose of private study or research.

- You may not further distribute the material or use it for any profit-making activity or commercial gain

- You may freely distribute the URL identifying the publication in the public portal 


\section{Accepted Manuscript}

An eco-efficiency evaluation of community-scale rainwater and stormwater harvesting in Aarhus, Denmark

Maria Faragò, Sarah Brudler, Berit Godskesen, Martin Rygaard

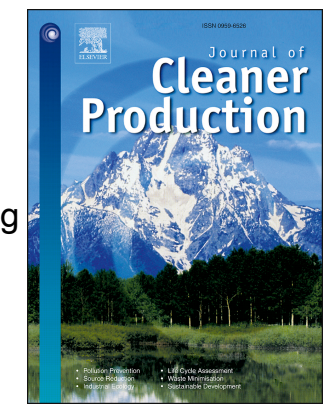

PII:

S0959-6526(19)30290-2

DOI:

https://doi.org/10.1016/j.jclepro.2019.01.265

Reference: JCLP 15652

To appear in: Journal of Cleaner Production

Received Date: 28 September 2018

Revised Date: 2 January 2019

Accepted Date: 23 January 2019

Please cite this article as: Faragò M, Brudler S, Godskesen B, Rygaard M, An eco-efficiency evaluation of community-scale rainwater and stormwater harvesting in Aarhus, Denmark, Journal of Cleaner Production (2019), doi: https://doi.org/10.1016/j.jclepro.2019.01.265.

This is a PDF file of an unedited manuscript that has been accepted for publication. As a service to our customers we are providing this early version of the manuscript. The manuscript will undergo copyediting, typesetting, and review of the resulting proof before it is published in its final form. Please note that during the production process errors may be discovered which could affect the content, and all legal disclaimers that apply to the journal pertain. 


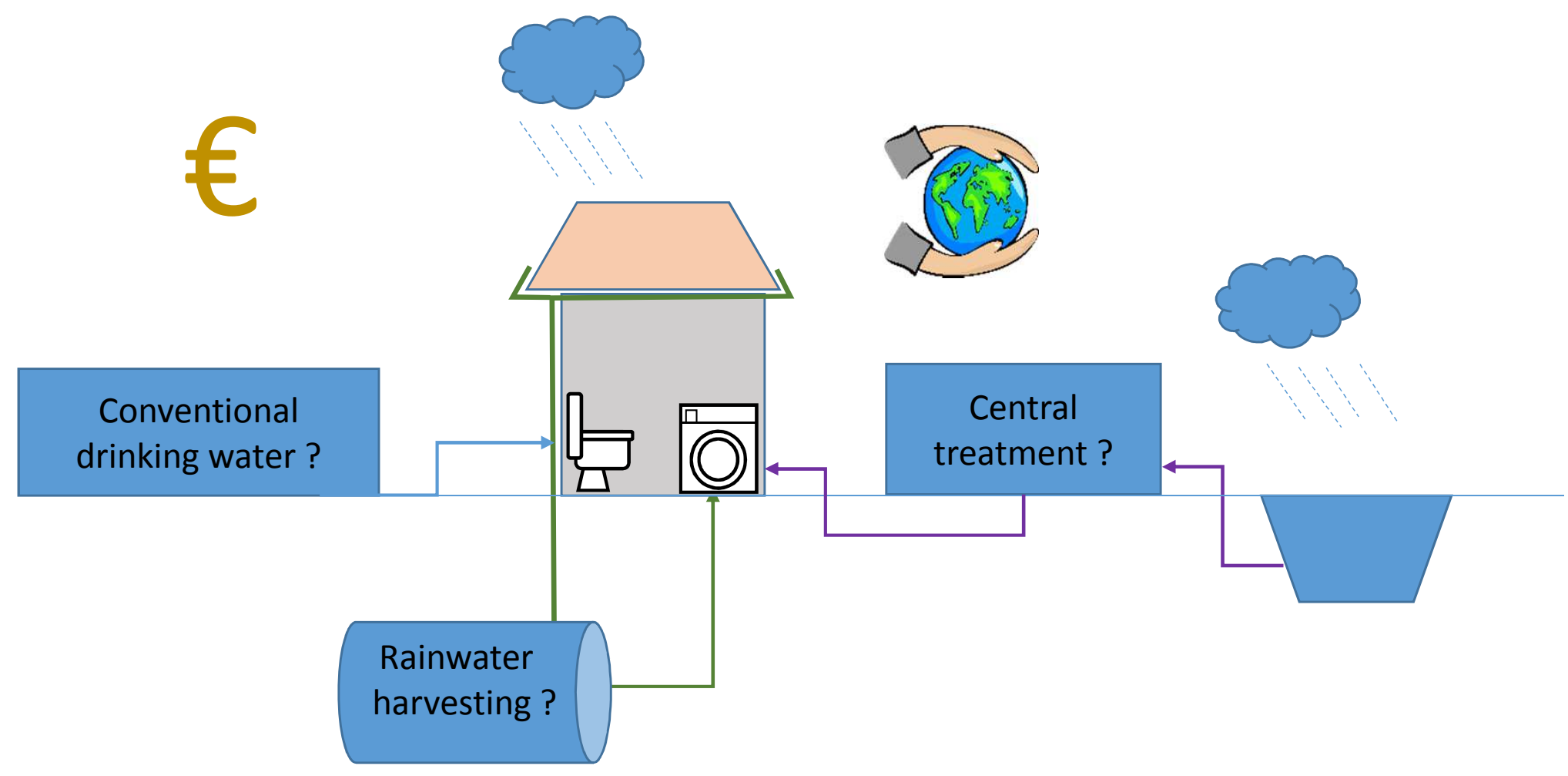


1 An eco-efficiency evaluation of community-scale rainwater and stormwater harvesting in

Aarhus, Denmark

3 Maria Faragò $^{\mathrm{a}}$, Sarah Brudler ${ }^{\mathrm{a}}$, Berit Godskesen $^{\mathrm{a} *}$, Martin Rygaard ${ }^{\mathrm{a}}$

4

${ }^{a}$ Urban Water Systems, Department of Environmental Engineering, Technical University of

Denmark, Bygningstorvet, Building 115, 2800 Lyngby, Denmark

${ }^{\mathrm{b}}$ VCS Denmark, Vandværksvej 7, 5000 Odense, Denmark

*Corresponding author:

email: berg@env.dtu.dk; Tel: (+45) 45251606

Abbreviations $^{1}$

\section{Abstract}

Urban areas in Denmark are currently challenged by the increase in extreme precipitation events, resulting in heightened flood risk, and higher water stress caused by population growth. Therefore, we need to diversify water resources and reshape stormwater management.

Our study evaluated the potential for increasing economic value while reducing the environmental impacts of implementing new concepts for non-potable rainwater use in a new urban development. We analysed five alternatives: a conventional groundwater-based drinking water system (A0-GW),

\footnotetext{
${ }^{1}$ CT: Centralised treatment; DW: Drinking water; FU: Functional unit; GW: Groundwater; LCA: Life cycle assessment; PVA: Processes generating value added; PVL: Processes generating value loss; RO: Reverse osmosis; RWH: Rainwater harvesting; SW: Secondary water; SWTP: Secondary water treatment plant; TVA: Total value added; UF: Ultrafiltration; UV: Ultraviolet; VA: Value added; WWTP: Wastewater treatment plant.
} 
three types of centralised ways of treating runoff collected from impervious areas (CT1-CT3) and a decentralised system for rainwater harvesting (DT-RWH). All five alternatives included stormwater collection with a system of basins and trenches for flood protection.

Potential environmental impacts were quantified by life cycle assessment (LCA), while the economic system value was assessed in terms of total value added (TVA). The LCA and TVA were evaluated over the entire water chain, including effects at the end-user level and an estimation of the single economic added value for each stakeholder. A combined LCA and TVA provided an assessment of eco-efficiency.

The four runoff-based alternatives exhibited up to $95 \%$ reduced freshwater depletion impacts compared to the conventional drinking water system. In all alternatives, more than $94 \%$ of the ecotoxicity impacts were due to the discharge of metals (zinc and copper) from runoff into freshwater, and the three centralised treatment alternatives (CT1-CT3) reduced ecotoxicity by $80 \%$. Overall, the two centralised ultrafiltration plants (CT1-CT2) showed the lowest effects in all impact categories, except for reserve base resource depletion, which was affected by stainless steel production.

CT1-CT2 also showed slightly higher TVA (app. +3 to 5\%) compared to conventional treatment. The TVA for CT3 and DT-RWH was found to be between $-14 \%$ and $-116 \%$ lower than conventional treatment. Except for the reserve base resource depletion category, CT1 and CT2 were considered the more eco-efficient alternatives compared to the conventional drinking water system.

\section{Keywords}

Water supply; secondary water treatment plant; non-potable water; environmental impacts; life cycle assessment; total value added 


\section{Introduction}

Urban water utilities are diversifying their resource and water handling systems. Diversification can be part of a strategy to build resilience to global changes, and sometimes it also promotes environmental consciousness in the supply areas (Rygaard et al., 2011b; Fragkou et al., 2016). Still, very few of these types of water system have been assessed rigorously for their environmental and economic impacts on society.

A changing climate is expected to cause an increase in extreme precipitation events in certain areas, and the resulting heightened flood risk can only be reduced by reshaping current stormwater management (Kundzewicz et al., 2007). From the perspective of supplementing existing water supply options and ensuring effective stormwater management for the future, urban water systems and technologies can be designed to support flood prevention while also use collected rainwater as a secondary, non-potable water supply. Such integrated stormwater management practices enhance the ecological value of the urban environment, increase flood safety levels and provide rainwater for domestic use - as demonstrated in an increasing number of studies (Domènech and Saurí, 2011; Gill et al., 2007; Wong et al., 2012).

In recent years, Denmark has been affected by climate change in the form of increased heavy rains and subsequent flooding in cities (Gregersen and Arnbjerg-Nielsen, 2012). The Danish government now requires the implementation of climate change adaptation plans for all of its cities, to mitigate damages from flooding and, for example, reduce the number of untreated overflows from combined sewer systems (Miljøstyrelsen, 2014). Sørup et al. (2012) showed that the integrated use and management of rainwater can reduce conventional drinking water demand and reduce the load on wastewater treatment plants by $38-50 \%$. 
This integrated approach is applied in Nye, a new development that upon completion will host 20,000 citizens in Aarhus, Denmark. It is the intention that Nye will be an environmentally lowimpact community and partly self-sufficient in terms of water through the integrated management of rain- and stormwater, the latter of which will be collected, stored and treated locally in a combined effort to avoid flood damage and to replace the use of drinking water for toilet flushing and laundry (Nye, 2016).

Life-cycle assessment (LCA) is used increasingly in the sustainability assessment of urban water systems, water supply technologies, water treatment, water recycling technologies (Amini et al., 2015; Fang et al., 2016; Ghimire et al., 2017; Godskesen et al., 2013; Igos et al., 2014; Jeong et al., 2015; Lam et al., 2017; Li et al., 2014) and reclaimed wastewater treatment for non-potable urban reuse (e.g. Opher and Friedler, 2016). LCAs have also been used to assess stormwater management systems for flood prevention (Petit-Boix et al., 2015; Brudler et al., 2016). Jeong et al. (2016) quantified the environmental impacts of a hybrid water system aiming at collectively controlling stormwater, harvesting rainwater for non-potable water reuse and providing potable water through a conventional water system. Their results show that from an LCA perspective, hybrid systems have higher impacts than conventional systems, if implemented in low population density areas, while showing comparable performance as population density increases. Their assessment does not, however, include the effect at the end-user level or a quantification of the economic effects.

Some authors have expanded the environmental assessment with economic impacts for urban water systems by estimating the total economic value added (TVA) and providing eco-efficiency indicators (Angelis-Dimakis et al., 2016; Ribarova et al., 2013; Stanchev and Ribarova, 2016), while others have assessed the eco-efficiency of flood prevention actions in cities (Petit-Boix et al., 2015; Petit-Boix et al., 2016). Arampatzsis et al. (2016) state that eco-efficiency indicators applied 
87

88

89

90

91

92

93

94

95

96

97

98

99

100

101

102

103

104

105

106

107

108

109

to real case studies are lacking, and they highlight the usefulness of the eco-efficiency tool for comparing different alternatives or improvements for the same system.

Our study expands understanding of the environmental and economic impacts that stem from changing conventional water management to an integrated and partly decentralised system in light of climate change. We aim to:

- Develop a generic method that combines economic and environmental assessments for an ecoefficiency evaluation of water systems;

- Comprehensively quantify and relate environmental impacts to economic effects throughout an urban water system's water chain;

- Assess the economic added value for each of the directly involved stakeholders;

- Quantitatively support the planning and decision-making process for the implementation of a new drinking water and stormwater management system in Nye.

\section{(1)}




\section{Materials and methods}

\subsection{Study Area}

The first phase of the new urban development at Nye comprises 18 hectares and will accommodate 2,000 inhabitants upon completion, serving as a model for the future development of up to 150 hectares. In total, $79 \%$ of the properties will be single-family houses, and the remaining $21 \%$ will be housing units. The average annual temperature of the area is app. $8^{\circ} \mathrm{C}$, with daily values between $4^{\mathrm{o}} \mathrm{C}$ in January and $20.1^{\circ} \mathrm{C}$ in July (DMI, 2018). The average annual precipitation for the area is $688 \mathrm{~mm}$, the projected maximum 1-year return period rainfall is $31 \mathrm{~mm} / 24 \mathrm{hr}$, and for a 10 -year return period it is $52 \mathrm{~mm} / 24 \mathrm{hr}$ (Bülow et al., 2014). In Nye, rain and stormwater will be collected in open trenches and channels and stored in surface basins, which will prevent flooding during events with a return period of up to 10 years, while the trenches will have a 5-year return period. Green areas and parking areas have been designed to retain water until it can be discharged into the trenches during extreme events, with return periods over 10 years. Additionally, the basins and trenches will provide important recreational and aesthetic value by introducing green and blue elements into the urban environment.

The area is subdivided into four sub-catchments with individual basins, all of which will ultimately discharge into the same basin (Fig. 1).

\subsubsection{Alternative definitions}

Five different alternatives for providing water for toilet flushing and laundry were evaluated in this study (Table 1). The baseline was defined as business-as-usual, i.e. a conventional drinking water system $(\mathrm{A} 0-\mathrm{GW})$, where treated groundwater $(\mathrm{GW})$ is used for potable and non-potable purposes. Three alternatives (CT1-CT3) involved the central treatment of stormwater (CT) in a secondary water treatment plant (SWTP), from where treated water is distributed to households for nonpotable purposes. The alternatives differed regarding the treatment technology: CT1 UF-UV 
Table 1. Key processes and effects of the evaluated alternatives. DW: drinking water, SWTP: secondary water treatment plant, WWTP: wastewater treatment plant. Additional information is found in Appendix A 141 in the Supplementary Material.

\begin{tabular}{|c|c|c|c|c|c|}
\hline Alternative & Intake & Treatment & Distribution & Use & $\begin{array}{l}\text { Discharge to } \\
\text { freshwater }\end{array}$ \\
\hline A0-GW & $\begin{array}{l}\text { Groundwater } \\
\text { abstraction }\end{array}$ & $\begin{array}{l}\text { Sand filtration and } \\
\text { aeration at } \\
\text { conventional } \\
\text { waterworks }\end{array}$ & $\begin{array}{l}\text { DW pipes from } \\
\text { waterworks to end- } \\
\text { users, supplying } \\
\text { drinking water for all } \\
\text { uses }\end{array}$ & $\begin{array}{l}\text { Potable/non- } \\
\text { potable. Effects of } \\
\text { water hardness of } \\
265 \mathrm{mg} / \mathrm{CaCO}_{3} \\
\text { on electricity and } \\
\text { laundry detergent } \\
\text { consumption }\end{array}$ & $\begin{array}{l}\text { Pollutants in } \\
\text { stormwater are } \\
\text { partly removed } \\
\text { through vegetation } \\
\text { in the trenches and } \\
\text { sedimentation in } \\
\text { the basins, before } \\
\text { discharge. } \\
\text { Household } \\
\text { wastewater is } \\
\text { treated at a WWTP } \\
\text { prior to discharge. }\end{array}$ \\
\hline $\begin{array}{l}\text { CT1 UF- } \\
\text { UV }\end{array}$ & $\begin{array}{l}\text { Rainwater/stormwater } \\
\text { collection from roofs } \\
\text { and roads. } \\
\text { Stormwater collected } \\
\text { through a system of } \\
\text { wet basins and } \\
\text { channels }\end{array}$ & $\begin{array}{l}\text { Centralised SWTP } \\
\text { with a capacity of } 6 \\
\mathrm{~m}^{3} / \mathrm{h} \text { located at } \\
\text { basin (D). } \\
\text { Treatment steps: } \\
\text { sand filter, pre-filter } \\
(300 \mu \mathrm{m}) \text {, } \\
\text { ultrafiltration, } \\
\text { storage tank ( } 60 \\
\left.\mathrm{~m}^{3}\right) \text {, UV- } \\
\text { disinfection }\end{array}$ & $\begin{array}{l}\text { Dual pipe distribution: } \\
\text { conventional drinking } \\
\text { water pipe system as in } \\
\text { A0-GW supplying } \\
\text { potable water, and a } \\
\text { secondary water pipe } \\
\text { system for treated } \\
\text { rainwater/stormwater } \\
\text { from the SWTP for } \\
\text { non-potable uses (toilet } \\
\text { flushing and laundry) }\end{array}$ & $\begin{array}{l}\text { Non-potable. } \\
\text { Effects of water } \\
\text { hardness of } 145 \\
\mathrm{mg} / \mathrm{l} \mathrm{CaCO}_{3} \text { on } \\
\text { electricity and } \\
\text { laundry detergent } \\
\text { consumption }\end{array}$ & $\begin{array}{l}\text { Pollutants in } \\
\text { stormwater are } \\
\text { partly removed } \\
\text { through vegetation } \\
\text { in the trenches and } \\
\text { sedimentation in } \\
\text { the basins. } \\
\text { Reject water from } \\
\text { the SWTP is } \\
\text { discharged directly } \\
\text { to a freshwater } \\
\text { recipient. Non- } \\
\text { potable household } \\
\text { wastewater is } \\
\text { treated as in A0- } \\
\text { GW }\end{array}$ \\
\hline $\begin{array}{l}\text { CT2 UF- } \\
\mathrm{H}_{2} \mathrm{O}_{2}\end{array}$ & As for CT1 UF-UV & $\begin{array}{l}\text { As for CT1 UF-UV, } \\
\text { but UV replaced } \\
\text { with a novel on-site } \\
\text { hydrogen peroxide }\end{array}$ & As for CT1 UF-UV & $\begin{array}{l}\text { As for CT1 UF- } \\
\text { UV }\end{array}$ & $\begin{array}{l}\text { As for CT1 UF- } \\
\text { UV }\end{array}$ \\
\hline $\begin{array}{l}\text { CT3 RO- } \\
\text { UV }\end{array}$ & As for CT1 UF-UV & $\begin{array}{l}\text { As for CT1 UF-UV } \\
\text { but with an } \\
\text { additional reverse } \\
\text { osmosis after UF } \\
\text { pre-treatment } \\
\end{array}$ & As for CT1 UF-UV & $\begin{array}{l}\text { As for CT1 UF- } \\
\text { UV }\end{array}$ & $\begin{array}{l}\text { As for CT1 UF- } \\
\text { UV }\end{array}$ \\
\hline
\end{tabular}




\begin{tabular}{|c|c|c|c|c|c|}
\hline DT-RWH & $\begin{array}{l}\text { Rainwater collection } \\
\text { from roofs }\end{array}$ & $\begin{array}{l}\text { Establishment of } \\
273 \text { private } \\
\text { decentralised } \\
\text { rainwater harvesting } \\
\text { (RWH) systems } \\
\text { whose components } \\
\text { are: stainless steel } \\
\text { filters, underground } \\
\text { storage tanks ( } 2 \\
\mathrm{~m}^{3} / \text { tank), pumps }\end{array}$ & $\begin{array}{l}\text { Piping system from the } \\
\text { underground tanks to } \\
\text { end-users }\end{array}$ & $\begin{array}{l}\text { As for CT1 UF- } \\
\text { UV }\end{array}$ & $\begin{array}{l}\text { Reject from the } \\
\text { RWHs is } \\
\text { connected to the } \\
\text { sewer system and } \\
\text { treated at a WWTP } \\
\text { discharging to a } \\
\text { freshwater } \\
\text { recipient. } \\
\text { Pollutants in runoff } \\
\text { from non-roof } \\
\text { areas are removed } \\
\text { partly through } \\
\text { vegetation in the } \\
\text { trenches and } \\
\text { sedimentation in } \\
\text { the basins before } \\
\text { discharge to the } \\
\text { freshwater } \\
\text { recipient. } \\
\text { Non-potable } \\
\text { household } \\
\text { wastewater treated } \\
\text { as in A0-GW. }\end{array}$ \\
\hline
\end{tabular}

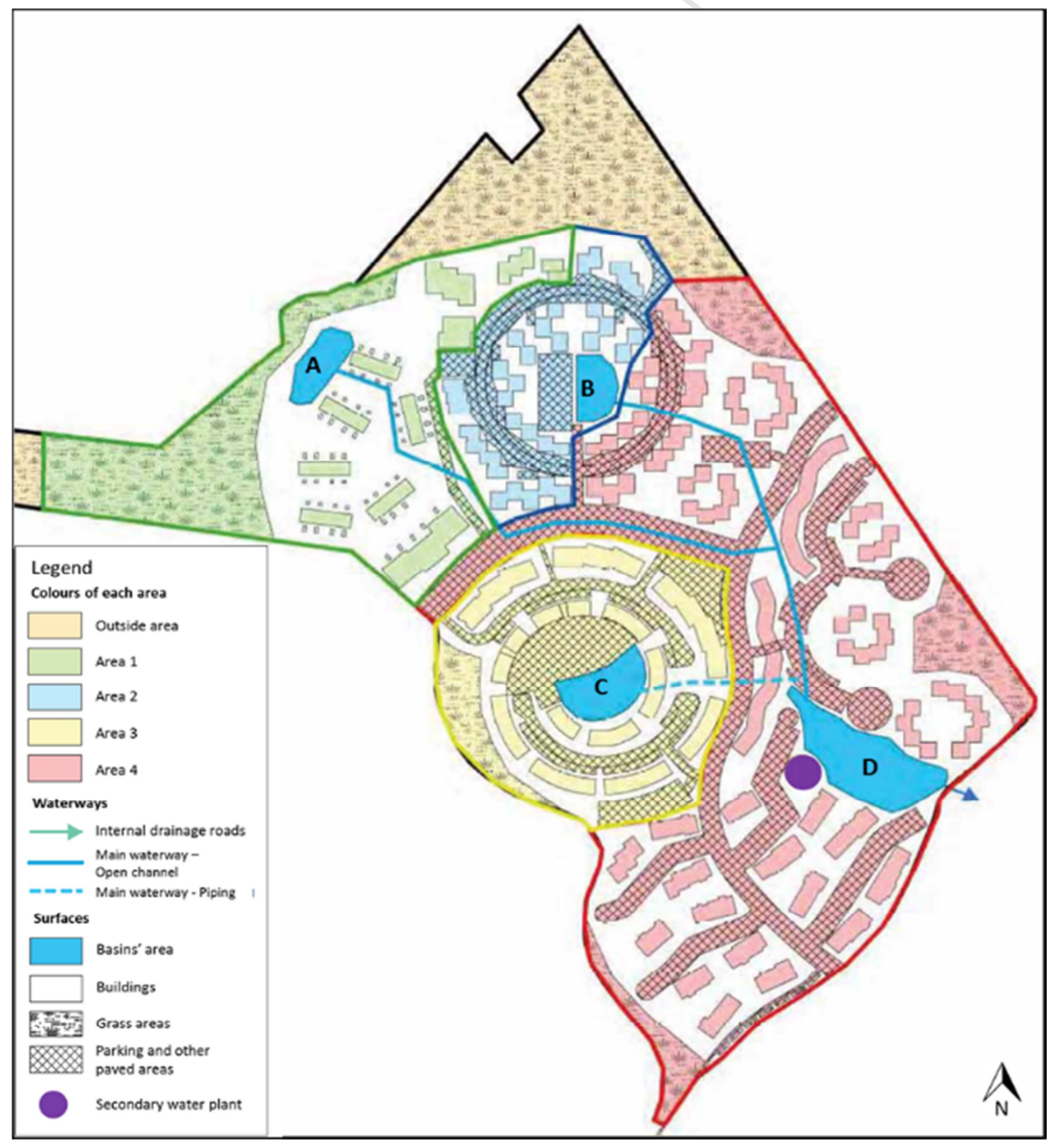


<Fig. 1>

145

\subsection{Eco-efficiency framework}

Eco-efficiency involves four steps: a goal and scope definition, an environmental assessment, an economic value assessment and the quantification of eco-efficiency and its interpretation (ISO, 2012).

\subsubsection{Goal and scope definition}

Our main goal is to quantify the economic and the environmental sustainability of alternatives for rainwater and stormwater collection and use, to meet the non-potable demand in Nye, and to compare such a novel water system's performance against a conventional groundwater-based drinking water supply. The functional unit (FU) was defined as the "Provision of 31,000 $\mathrm{m}^{3} /$ year of non-potable water, to 2,000 inhabitants in Nye, and the prevention of flooding according to defined municipal safety standards.”

\subsubsection{System boundaries and water balance}

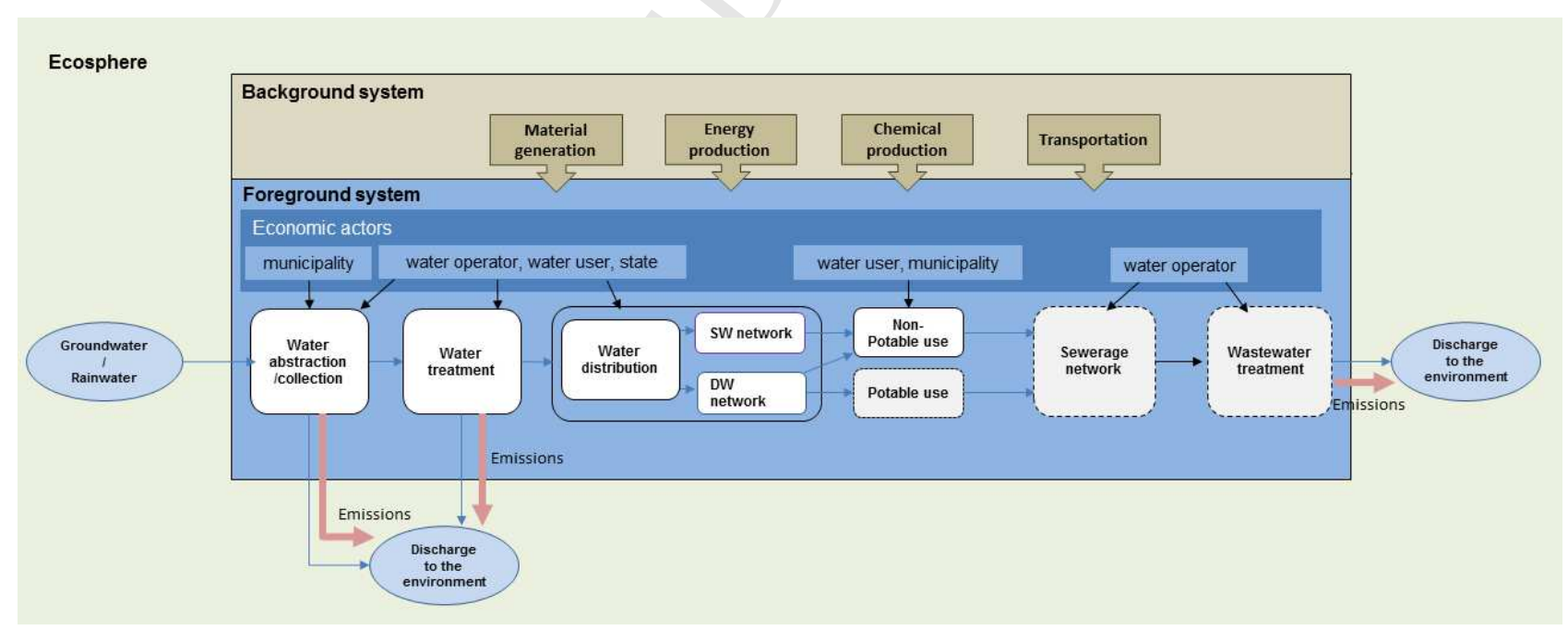

<Fig. 2>

System boundaries comprised groundwater abstraction, rainwater and stormwater collection, water distribution, water treatment, water use and discharges of polluted stormwater into the environment (Fig. 2). 
162 The total annual drinking water demand in Nye was estimated at $84,000 \mathrm{~m}^{3}$, while water used for 163 toilets and laundry was assumed to be $40 \%$ of the drinking water demand, i.e. $31,000 \mathrm{~m}^{3} /$ year 164 (DANVA, 2013). This corresponded to a total requirement for $33,477 \mathrm{~m}^{3} / y e a r$ of groundwater 165 abstraction in the business-as-usual alternative (Fig. 3), which includes $7.4 \%$ of water losses 166 (Aarhus Kommune, 2016b). Runoff collected through the systems of basins and trenches was 167 assumed to be $49,368 \mathrm{~m}^{3} /$ year (Fig. 3), with $76 \%$ collected from roofs, $20 \%$ from roads and $4 \%$ 168 from remaining impervious areas (Aarhus Vand, Personal communication).

169 In the CT alternatives, stormwater was collected from all impervious areas, while only roof runoff 170 was collected in the DT-RWH alternative. The three CT alternatives had an assumed reject stream 171 from the SWTP of $13 \%$ for the UF treatment and $25 \%$ for the RO treatment (Fig. 3). In the CT 172 alternatives, the wastewater stream carrying water rejected from the SWTP was assumed to be 173 discharged into the freshwater recipient. In the RWH, the collected roof runoff was filtrated through 174 a stainless steel filter with an assumed reject water of $2 \%$. The reject water from the RWH filter was 175 assumed to be discharged into the sewer system and treated in the WWTP.

176 The five alternatives provide different water hardness levels, each of which affects electricity and 177 laundry detergent consumption in the use stage (Godskesen et al., 2012). The hardness of the 178 drinking water in Nye was estimated at $265 \mathrm{mg} / \mathrm{l}$ as $\mathrm{CaCO}_{3}$, which is considered very hard (WHO, 179 2011). Although a water hardness of $45 \mathrm{mg} / \mathrm{l}$ as $\mathrm{CaCO}_{3}$ is normally considered a representative 180 value for surface water (Rygaard et al., 2011a), the hardness of rainwater and stormwater was 181 assumed to be at $145 \mathrm{mg} / \mathrm{l}$, with the assumption that no further improvements can be made at a 182 water hardness below $145 \mathrm{mg} / \mathrm{l}$ as $\mathrm{CaCO}_{3}$. Values for electricity and laundry detergent consumption 183 at $145 \mathrm{mg} / \mathrm{l}$ were taken from Godskesen et al. (2012). 


\subsubsection{Assumptions}

185 The following key assumptions were made regarding system boundaries and the temporal scope:

- System life was assumed at 25 years.

- The production of drinking water for potable use did not differ between the alternatives and was excluded.

- The sewer system and wastewater treatment were not included in the analysis, because the total water demand in the system was assumed to be unchanged between the alternatives.

- Caused by dry weather periods, the runoff-based alternatives were assumed to receive 5\% of non-potable water demand from the conventional drinking water supply.

- There were no expected significant changes to the external conventional drinking water system infrastructure, and only changes to operations and maintenance were included in the assessment of $\mathrm{A} 0-\mathrm{GW}$.

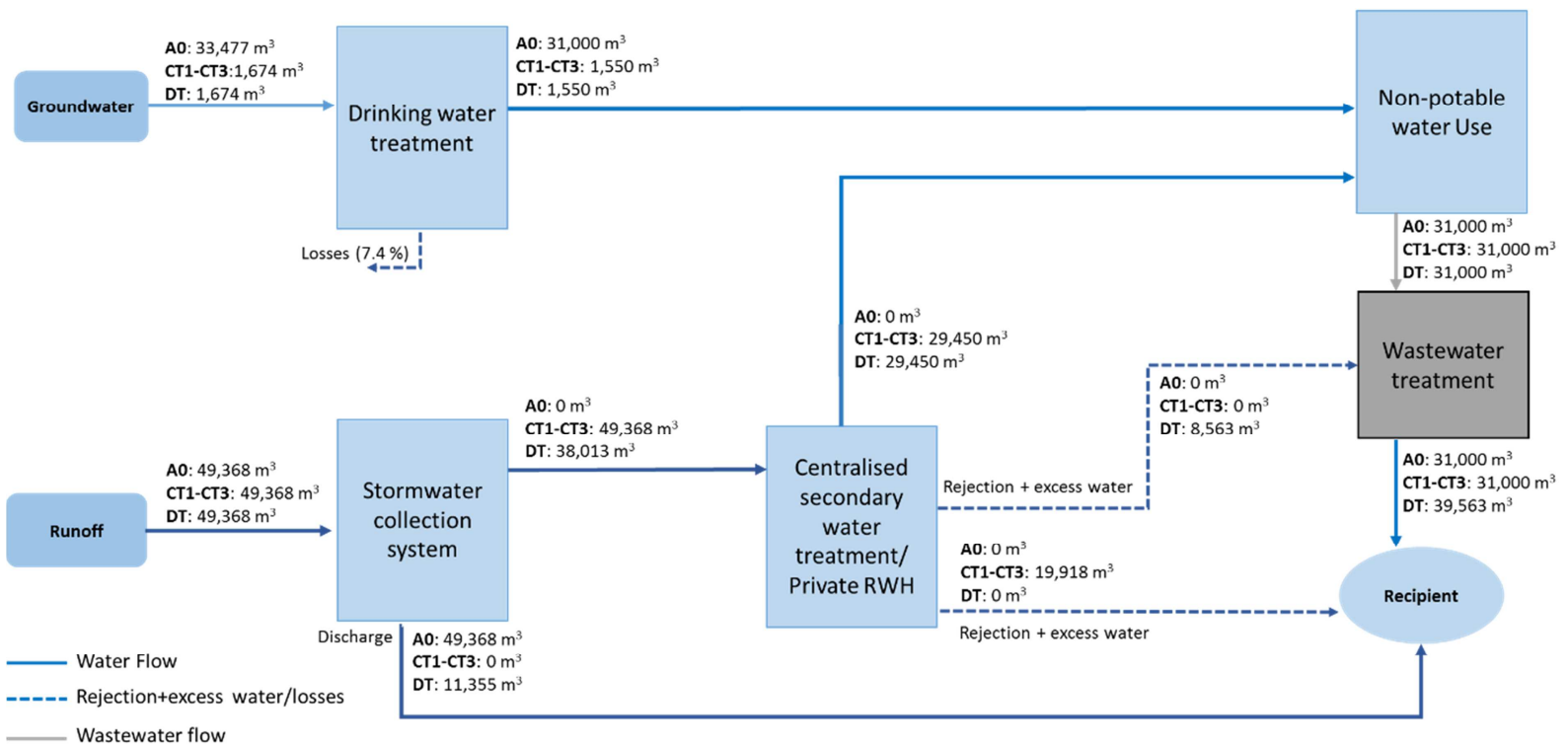

<ig. 3> 
199

200

201

202

203

\subsubsection{Data inventory}

The life cycle inventory collated marginal changes affected by the choice of one alternative over the other. An inventory of the water use stage included the relative increase in electricity and laundry detergent consumption caused by the harder water in A0-GW.

For the LCA, input data in the foreground processes specific to the alternatives were collected from planning documents, databases, information provided mostly by the utility and a literature search. Concentrations of copper and zinc in stormwater, which have been identified as major contributors to ecotoxicity, were taken from Brudler et al. (unpublished-a). The flow of pollutants through the system was tracked, taking into account pollutant removal at different stage via sedimentation or treatment (Table A.3 in the Supplementary Material).

Background processes, including electricity production, chemical production and material production, were modelled using the Eco-invent database version 3.3 (Wernet et al., 2016) and EASETECH v. 2.0 (Clavreul et al., 2014; Damgaard et al., 2016). When it was not possible to find background processes specific to Denmark, other processes for Europe or the rest of the world were used.

Investment, operational costs and income related to water management were calculated based on data from the water utility Aarhus Vand and supplemented with statistics from the literature.

\subsubsection{Environmental impact assessment}

The impacts were calculated according to the International Reference Life Cycle Data System (ILCD) (EC-JRC, 2010) for the following categories: reserve base resource depletion (RD-reserve), fossil resource depletion (RD-fossil), climate change (CC), ecotoxicity (E-TOX) and particulate matter (PM). Freshwater depletion (FD) was calculated as suggested for GW-based water supplies (Gejl et al., 2018). Calculations are provided in Appendix B in the Supplementary Material. 
Impacts were normalised according to normalisation references (Table B.1 in the Supplementary Material) and expressed in person equivalent (PE).

\subsubsection{Economic assessment}

Each alternative was assessed in terms of total economic value added (TVA) due to water use and stormwater management at the community scale. The TVA formulation was modified from Angelis-Dimakis et al. (2016) and Stanchev and Ribarova (2016) to be able to include incentives and other additional added and lost values in each stakeholder:

$T V A\left[\frac{E U R}{\text { year }}\right]=\sum_{s=1}^{n}\left(\mathrm{VA}_{\mathrm{s}}\right)=\sum_{s=1}^{n}\left(P V A_{s}-P V L_{s}\right)$

where TVA is the sum of each single economic value added (VAs) for each involved stakeholder (s) throughout the entire water chain (Table 2). VA is value added (PVAs) minus value loss (PVLs) for each process. In our definition, we excluded salary form the value loss, implying that salary is considered a value to society.

PVA for the water operator corresponds to direct incomes generated from the delivery of the water service, while losses are investment and operational costs for water infrastructure and treatment, as well as state water taxes.

The PVA for the water user corresponds to the economic value from water use (EVU), which is constant across alternatives since it was assumed that the value of non-potable water does not change according to the source (groundwater or rainwater). As suggested by Angelis-Dimakis et al. (2016), EVU was also assumed to be equal to the current water supply fee for the water service.

This is in line with the evaluation from the water utility Aarhus Vand, which states that they do not expect a significant change in non-potable water price if treated rainwater is used instead of groundwater. 
In the case of private RWH, the water user will benefit from economic incentives for private RWH paid by the municipality. PVL for the water user linked to water processes involves non-potable water supply fees, the costs of electricity and detergent consumption for laundry and investment and operational costs for implementing private RWH.

The municipality is responsible for the investment costs for the stormwater collection system (PVL). In the case of private RWH, the municipality needs to give incentives that constitute an outflow payment in the municipality budget (PVL). Indirect added values such as recreational or aesthetic benefits were not assessed.

From Table 2, the PVLs include primarily outflow payments (e.g. investment and operational costs for water treatment, water fees and water taxes). Investment costs, for instance for new drinking water pipes, new treatment facilities and investment costs for membrane replacement and decoupling incentives, were annualised as:

$$
C_{\text {Investment }}[\text { EUR/year }]=P\left(\frac{r(1+r)^{n}}{(1+r)^{n}-1}\right)
$$

where $P$ is the initial total investment (EUR), $r$ is the annual discount rate (assumed to be $3.87 \%$ ), and $n$ is the lifetime in years (assumed to be 25 years). Equation 2 implies that all system components have no value at the end of their life.

Table 2. Breakdown of the processes generating added or lost values for stakeholders.

\begin{tabular}{lll}
\hline Stakeholders (s) & Added values (PVAs) & Loss of values (PVLs) \\
\hline Water Operator & - Direct incomes generated by & - Operational costs of water abstraction, \\
the non-potable water supply & treatment, transport (energy, \\
service. The water fee for the & chemicals, materials replacement) \\
secondary water supply & - Investment costs of water \\
derived from the treated & infrastructure \\
rainwater (alternatives CT1- & \\
& CT3, DT) was assumed to be \\
& the same as the conventional \\
& water supply fee, based on \\
& information given by the water & \\
&
\end{tabular}




\begin{tabular}{|c|c|c|}
\hline & utility & \\
\hline Water User & $\begin{array}{l}\text {-Economic value from water } \\
\text { use (EVU) } \\
\text { - Incentives for private RWH }\end{array}$ & $\begin{array}{l}\text { - Non-potable water supply fees } \\
\text { - Costs of electricity consumption and } \\
\text { laundry detergents during the water } \\
\text { use stage } \\
\text { - Investment and operational costs for } \\
\text { the implementation of private RWH }\end{array}$ \\
\hline State & $\begin{array}{l}\text { - Income generated by state } \\
\text { water taxes }\end{array}$ & - \\
\hline Municipality & - & $\begin{array}{l}\text { - Investment costs for the construction } \\
\text { of basins and trenches } \\
\text { - Costs for incentives for private RWH }\end{array}$ \\
\hline
\end{tabular}

\subsubsection{Eco-efficiency}

The TVA and the environmental impacts have different units, and they were therefore normalised in the range $[0,1]$ :

$$
x_{i, n o r m}=\frac{x_{i}-\min (X)}{\max (\boldsymbol{X})-\min (\boldsymbol{X})}
$$

267 Where $\mathrm{i}$ is the $\mathrm{i}^{\text {th }}$ alternative, $\mathrm{x}_{\mathrm{i}, \text { norm }}$ is the $\mathrm{i}^{\text {th }}$ normalised TVA or the inverse of LCA impact 268 category, $X=\left(x_{1}, \ldots, x_{n}\right)$, i.e. the TVA or the inverse of LCA dataset. The choice of the inverse of the 269 LCA impact in equation 3, was made to harmonise the meaning of the normalised scores such that 270 "one" represents the best score for economy or environment and the worst score is indicated by 271 "zero". An alternative which has a normalised score of one in both TVA and LCA shows the best 272 performance in terms of economic value added and reduced environmental impacts.

273 An alternative was considered eco-innovative compared to baseline if it provided both increased 274 TVA and a reduction of environmental impacts (Levidow et al., 2016), while considered 275 deteriorative if it provided a decrease in TVA and an increase in environmental impacts. An 276 alternative could not be determined eco-innovative if it fell into the trade-off zone, meaning that it 277 improved the TVA but not the LCA performance or vice versa. 


\subsubsection{Scenario analysis}

279 Our study was characterised by intrinsic uncertainties that might affect the final findings. The sensitivity of both economic performance and environmental impacts was tested by varying the need for dry weather top-up water, and the impacts from water quality in the use stage (Table 3).

282 Further details of the scenario analysis are provided in Appendix C in the Supplementary Material.

283 Table 3. Parameters selected for the scenario analysis.

\begin{tabular}{|c|c|c|c|}
\hline Parameter (p) & Alternative & Baseline & Changed \\
\hline $\begin{array}{l}\text { 1. The amount of drinking } \\
\text { water used during dry- } \\
\text { weather periods to fulfil } \\
\text { non-potable water demand }\end{array}$ & $\begin{array}{l}\text { CT1-CT3, } \\
\text { DT }\end{array}$ & $\begin{array}{l}5 \% \text { of the yearly non- } \\
\text { potable water demand } \\
\left(1,550 \mathrm{~m}^{3} / \text { year }\right)\end{array}$ & $\begin{array}{l}20 \% \text { of the yearly non-potable water } \\
\text { demand }\left(6,200 \mathrm{~m}^{3} / \text { year }\right)\end{array}$ \\
\hline $\begin{array}{l}\text { 2. The effect of different } \\
\text { water hardness on electricity } \\
\text { and laundry detergents' } \\
\text { consumption at the end-user } \\
\text { level }\end{array}$ & $\begin{array}{l}\text { CT1-CT3, } \\
\text { DT }\end{array}$ & $\begin{array}{l}\text { Values at } 145 \mathrm{mg} / \mathrm{l} \mathrm{CaCO} \\
\text { from Godskesen et al. } \\
(2012)\end{array}$ & $\begin{array}{l}\text { Estimated values at } 45 \mathrm{mg} / \mathrm{CaCO}_{3} \\
\text { through linear interpolation based on } \\
\text { values from Godskesen et al. (2012) } \\
\text { (Fig. D.1-2 in the Supplementary } \\
\text { Material). }\end{array}$ \\
\hline $\begin{array}{l}\text { 3. Excluded effect of water } \\
\text { hardness on electricity and } \\
\text { laundry detergent } \\
\text { consumption at the end-user } \\
\text { level }\end{array}$ & $\begin{array}{l}\text { A0, CT1- } \\
\text { CT3, DT }\end{array}$ & $\begin{array}{l}\text { Values at } 145 \mathrm{mg} / 1 \mathrm{CaCO}_{3} \\
\text { from Godskesen et al. } \\
(2012)\end{array}$ & Excluded effect of water hardness \\
\hline
\end{tabular}




\section{Results and discussion}

\subsection{Inventory analysis}

The inventory revealed a marked variance in energy, chemical and material use across the five

alternatives (Table 4). Inventory data for the five alternatives showed 2.4 times higher electricity consumption during treatment in the RO unit (CT3 RO-UV), and 1.5 times higher electricity for pumping in the private RWH (DT-RWH) compared to A0. Notably, A0-GW saw significant extra electricity demand during the use stage, due to the additional electricity consumption for laundry induced by the hardness of the drinking water. The UF-based plants (CT1 and CT2) required 600$700 \mathrm{~kg}$ more chemicals per year for cleaning compared to sand filter and RO-based treatment. The decentralised RWH (DT-RWH) required up to 14 times as much plastic as any of the other alternatives, due to the 273 PVC underground storage tanks. Conversely, the centralised treatment plant (CT1-CT3) had a nine to 30 times higher stainless steel demand than DT-RWH and A0-GW, respectively, due to storage tanks, piping and cleaning tank equipment.

Table 4. Selected inventory of selected materials, resources, electricity, chemicals and transportation for all five alternatives. Values are expressed per FU, i.e. $31,000 \mathrm{~m}^{3}$ of produced non-potable water per year. The complete inventory can be found in Table E.1-E.3 in the Supplementary Material.

\begin{tabular}{|c|c|c|c|c|c|}
\hline$\infty$ & A0-GW & $\begin{array}{l}\text { CT1 UF- } \\
\text { UV }\end{array}$ & $\begin{array}{l}\text { CT2 UF- } \\
\mathrm{H}_{2} \mathrm{O}_{2}\end{array}$ & $\begin{array}{l}\text { CT3 RO- } \\
\text { UV }\end{array}$ & $\begin{array}{l}\text { DT- } \\
\text { RWH }\end{array}$ \\
\hline $\begin{array}{l}\text { Electricity consumption (treatment, } \\
\text { transportation and pumping) [kWh] }\end{array}$ & 17,676 & 9,435 & 9,931 & 41,759 & 25,684 \\
\hline $\begin{array}{l}\text { Electricity consumption during water } \\
\text { use }[\mathrm{kWh}]\end{array}$ & 7,280 & - & - & - & - \\
\hline $\begin{array}{l}\text { Laundry detergents consumption during } \\
\text { water use [kg] }\end{array}$ & 1,700 & - & - & - & - \\
\hline $\begin{array}{l}\text { Chemicals for cleaning UF membranes } \\
\text { [kg] }\end{array}$ & 0 & 659 & 659 & 66 & 0 \\
\hline $\begin{array}{l}\text { Chemicals for cleaning RO membranes } \\
\text { [kg] }\end{array}$ & 0 & 0 & 0 & 15 & 0 \\
\hline Plastics [kg] & 252 & 299 & 341 & 306 & 3,424 \\
\hline Stainless steel [kg] & 45 & 1,313 & 1,307 & 1,405 & 149 \\
\hline Bentonite for basins $[t]$ & 17.2 & 17.2 & 17.2 & 17.2 & 17.2 \\
\hline Gravel for trenches $[t]$ & 16.9 & 16.9 & 16.9 & 16.9 & 16.9 \\
\hline Transportation of materials[t.km] & 13,534 & 16,139 & 16,145 & 16,165 & 13,787 \\
\hline Groundwater withdrawal $\left[\mathrm{m}^{3}\right]$ & 33,477 & 1,674 & 1,674 & 1,674 & 1,674 \\
\hline
\end{tabular}




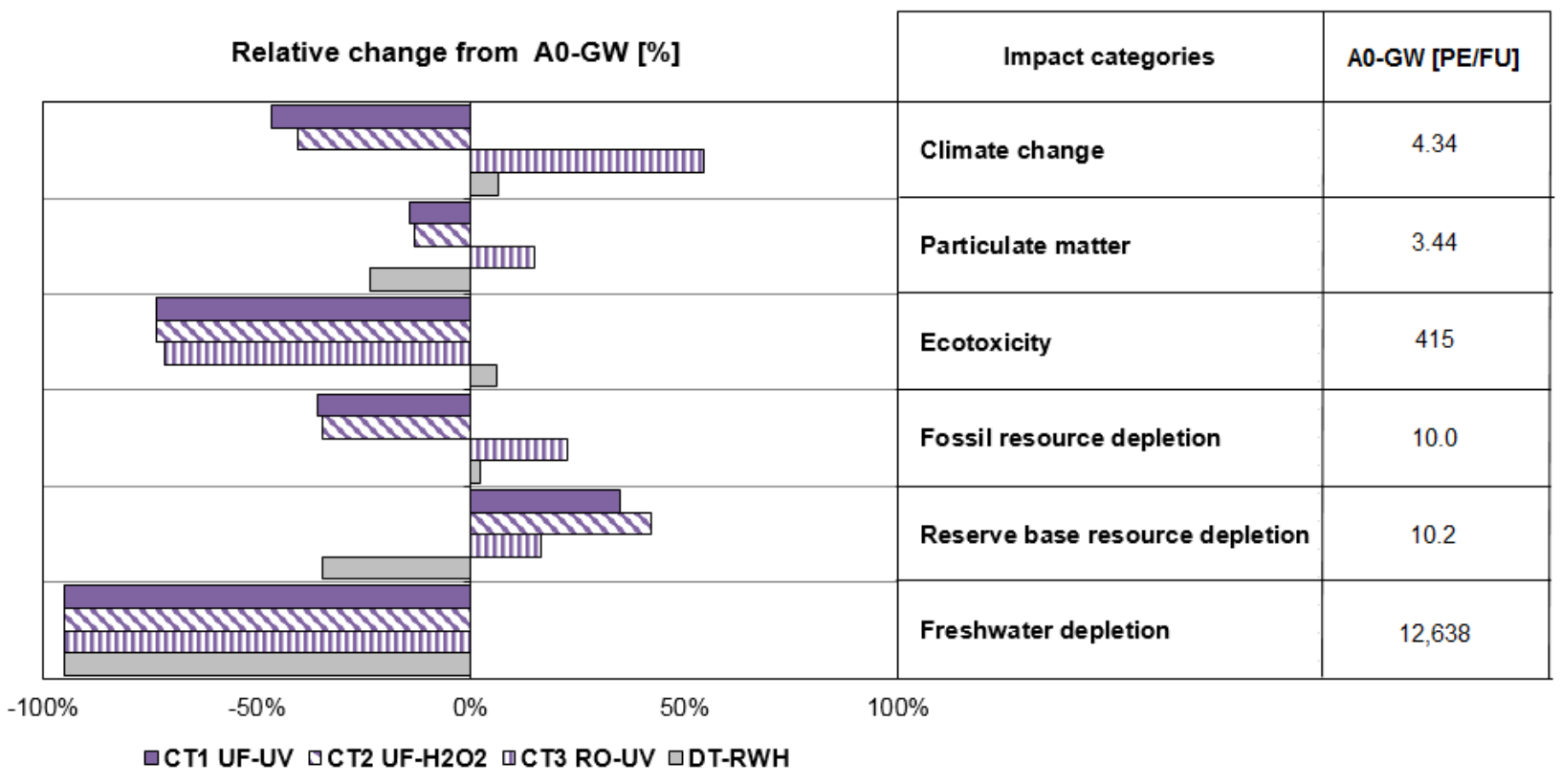

<Fig. 4>

Freshwater depletion impacts ranged from 632 to 12,638 PE across the alternatives. Impacts of freshwater depletion was up to four orders of magnitude higher than the other impact categories, partly explained by water being the main substance flow in the assessment.

The ecotoxicity impacts were the second highest between 110 and 440 PE (Fig. 4) and were caused primarily by discharges of polluted stormwater to the recipient (Fig. 5). The remaining categories showed impacts ranging from 2 to $14 \mathrm{PE}$.

The alternatives with rainwater and stormwater use caused lower impacts than the conventional drinking water system in almost all categories (Fig. 4) except for CT3 RO-UV, which had 15 to $54 \%$ higher impacts in four categories, i.e. climate change, particulate matter, fossil and reserve base resource depletion. The decentralised RWH (DT-RWH) performed similar to the conventional water supply in fossil resource depletion $(+2 \%$ relative change), while it was worse in climate change and ecotoxicity $(+6 \%$ relative change $)$. 
The two ultrafiltration plants, coupled either with UV (CT1 UF-UV) or with $\mathrm{H}_{2} \mathrm{O}_{2}$ disinfection (CT2 UF- $\mathrm{H}_{2} \mathrm{O}_{2}$ ), performed similarly (Fig. 4) (up to $4 \%$ difference) with reduced impacts compared to A0-GW in all categories, except for the reserve base resource depletion. CT1 and CT2 seem to be the most efficient alternatives regarding the electricity-related impact categories, namely climate change and fossil resource depletion. The RO treatment and private RWH systems showed up to three times higher impacts than the two ultrafiltration plants for these categories because of their higher electricity demands.

\subsubsection{Ecotoxicity}

Consistently in all of the alternatives, ecotoxicity impacts were caused by the local discharge of polluted runoff to the freshwater recipient (more than $94 \%$ of the total). These local effects have previously been found several orders of magnitude higher than those caused by other processes in the life cycle of urban water systems (Brudler et al., unpublished-b). The alternatives, CT1-CT3, had 297 to 305 PE fewer ecotoxicity impacts than A0-GW, which does not treat stormwater, and the only pollutant removal occurs in the basins and trenches. The private RWH had $26 \mathrm{PE}$ higher ecotoxicity than A0-GW, because roof runoff is discharged to the WWTP (directly as reject or after household use), which has relatively low removal efficiency for zinc, which is one of the main contributors to impacts in terms of stormwater discharge (Brudler et al., unpublished-b).

\subsubsection{Electricity consumption}

High climate change and fossil resource depletion impacts in A0-GW were caused primarily by the electricity consumption required to abstract, treat and distribute drinking water $\left(0.5 \mathrm{kWh} / \mathrm{m}^{3}\right)$. Additionally, the water hardness at the household level led to a $22 \%$ increase in climate change due to the higher electricity consumption and laundry detergent use compared to the four alternatives. This could also be offset by central softening of drinking water, which was not considered in our study (Godskesen et al., 2012). 
Electricity consumption for treatment in the CT alternatives (CT1-CT3) caused significant climate change and fossil resource depletion (Fig. 5). Total electricity consumption in the ultrafiltration plants (CT1-CT2) contributed between 48 and $51 \%$ of the climate change total and almost $26 \%$ of the fossil resource depletion, with electricity requirements for water distribution $\left(0.2 \mathrm{kWh} / \mathrm{m}^{3}\right)$ being the major contributor in this regard (33-37\% in climate change and 19\% in fossil resource depletion). These findings are in accordance with other studies assessing the life cycle impacts of water treatment processes, which highlight the importance of electricity consumption for pumping and water distribution (Tarantini and Ferri, 2001; Amores et al., 2013; Barjoveanu et al., 2014). Additionally, in our system, the transportation of materials for basins and trenches contributed $42 \%$ to the fossil resource depletion impacts of the two ultrafiltration plants. For the RO alternative (CT3 RO-UV), electricity consumption dominated climate change, fossil resource depletion and particulate matter impacts at $80 \%, 63 \%$, and $40 \%$, respectively, with electricity for the RO treatment $\left(0.75 \mathrm{Kwh} / \mathrm{m}^{3}\right)$ being the major contributor (Fig. 5).

Electricity for pumping water from the underground tanks into the decentralised RWH systems contributed $72 \%$ of the climate change, $46 \%$ of fossil resource depletion and $37 \%$ of particulate matter impacts. Also here, electricity for pumping was a key component in the RWH. A review of the energy intensity of RWH systems carried out by Vieira et al. (2014) revealed that there is a huge difference in the values used for energy intensity in theoretical studies (median energy intensity of $0.2 \mathrm{kWh} / \mathrm{m}^{3}$ ) compared to empirical studies (median energy intensity of $1.4 \mathrm{kWh} / \mathrm{m}^{3}$ ). This emphasises the need for a better understanding of energy use in local RWH and an improvement in energy efficiency for small-scale water supply pumping. In our study, the electricity demand for RWH was assumed at $0.8 \mathrm{kWh} / \mathrm{m}^{3}$ and as such it exceeded the $0.5 \mathrm{kWh} / \mathrm{m}^{3}$ needed for the conventional water supply system; however, including end use electricity consumption related to 

favourable.

365 and $29 \%$ in all three $\mathrm{CT}$ alternatives.

a)

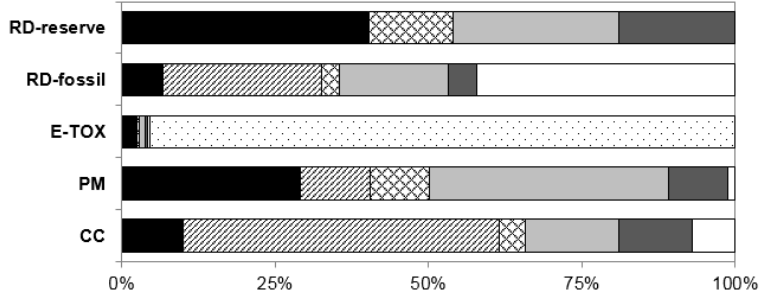

c)

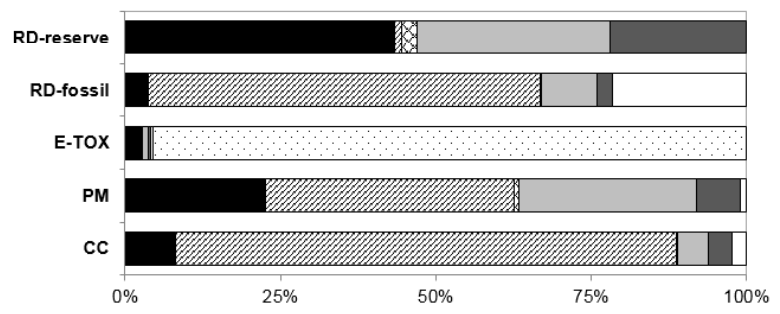

b)

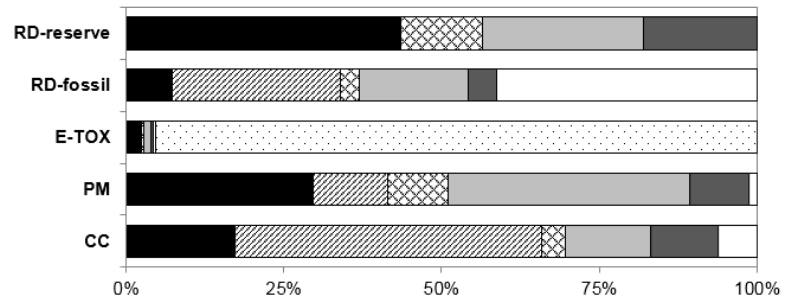

d)

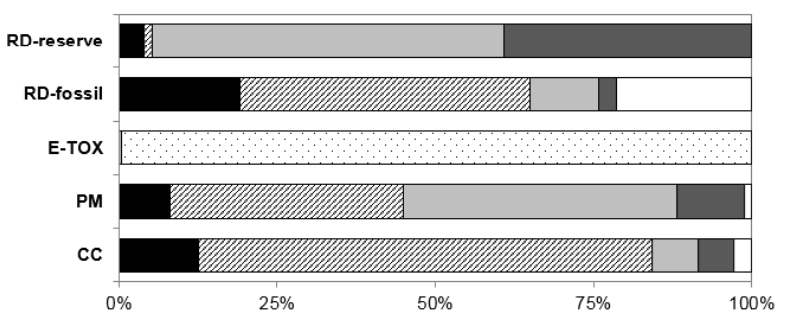

- Water treatment, Infrastructure $\square$ Basins $\square$ Runoff pollutants
Water treatment, Electricity $\square$ Trenches $\otimes$ Water treatment, Chemicals $\square$ Transportation 


\subsection{Economic assessment}

Table 5. Breakdown of the economic inventory for processes generating lost and added values, expressed in annual equivalent monetary unit (1,000 EUR/year). Operational costs for the water operator are the sum of water state taxes and operational costs for treatment. The input data for the inventory can be found in Table E.5 in the Supplementary Material.

\begin{tabular}{lccccc}
\hline & A0-GW & CT1 UF- & $\begin{array}{l}\text { CT2 UF- } \\
\text { UV2O2 }\end{array}$ & $\begin{array}{l}\text { CT3 RO- } \\
\text { UV }\end{array}$ & DT-RWH \\
\hline Water Operator & & & & & \\
\hline Investment costs & -0.4 & -8.9 & -8.3 & -8.3 & -0.4 \\
Operational costs & -36.7 & -37.3 & -38.9 & -46.6 & -1.8 \\
$\quad-$ Water state taxes & -31.5 & -33.0 & -33.0 & -33.0 & -1.6 \\
$\quad-$ Operational costs for treatment & -5.2 & -4.2 & -5.8 & -13.5 & -0.3 \\
Income from water service & 74.1 & 74.1 & 74.1 & 74.1 & 3.7 \\
\hline Water user & & & & & \\
\hline Investment costs & 0 & 0 & 0 & 0 & -60.4 \\
Operational costs & -84.0 & -74.1 & -74.1 & -74.1 & -11.0 \\
Economic value from the water use & 74.1 & 74.1 & 74.1 & 74.1 & 74.1 \\
Incentives for RWH & 0 & 0 & 0 & 0 & 73.2 \\
\hline State/Municipality & & & & & \\
\hline Investment costs for basins and & -13.3 & -13.3 & -13.3 & -13.3 & -86.5 \\
trenches, plus incentives & & & & \\
Income from water taxes & 31.5 & 33.0 & 33.0 & 33.0 & 1.6 \\
\hline TVA & 45.4 & 47.7 & 46.8 & 39.0 & -7.5 \\
\hline
\end{tabular}

The TVAs of the plants operated by the water utility (i.e. A0, CT1-CT3) were found to be within a narrow range of 39 to $48 \mathrm{tEUR}$, or 1.3 to $1.5 \mathrm{EUR}$ per $\mathrm{m}^{3}$ non-potable water (Table 5). The alternatives CT1 and CT2 showed a slightly higher TVA than the conventional drinking water supply system (between $+3 \%$ and $+5 \%$, i.e. 1.4-2.4 tEUR), while CT3 and DT-RWH worsened economic performance by -14\% (-6.4 tEUR) and -116\% (-53 tEUR), respectively (Fig. 6).

The investment costs of the water operator in A0-GW were lower than CT1-CT3, because the water operator has the current capacity to increase production without expanding its system in A0-GW (Table 5). Conversely, the operational costs of the centralised plants were found to be similar to A0$\mathrm{GW}(+2 \%,+6 \%)$ except for the RO alternative $(+27 \%)$, due to high electricity demand. 
The RWH increased the investment need of the individual households, but their operational costs were between 85 and $87 \%$ lower than for the other alternatives. The water users incur in lower operational costs in DT-RWH since they pay fees only for non-potable water during dry periods. The extra demand for electricity and laundry detergent consumption, due to the difference in water hardness, induced $13 \%$ higher operational costs for the end-user in A0, compared to the other alternatives.

The TVA of DT-RWH was the lowest, due to the municipal expenses for RWH incentives, which represent additional income for water users. Each household would receive incentives for private RWH of approximately 2.3 tEUR/household, which would partly offset household investment costs for the 273 RWH systems (app. 3 tEUR/unit). The reduced income for the water utility and the municipality expenses for RWH would render the DT-RWH non-beneficial from a communityscale economic point of view. However, if a future legislative framework made periodic checks by the water utility mandatory, this would end up as income for the water utility.

In line with the eco-efficiency assessment provided by Angelis-Dimakis et al. (2016) for two urban water systems in Bulgaria and Switzerland, our study showed that implementing improvements in conventional urban water management is always economically beneficial for the water user (Fig. 6) due to: reduced expenses for electricity and laundry detergent consumption (CT1-CT3, DT-RWH), reduced non-potable water supply fees and provision of municipal incentives for RWH (DT-RWH). 


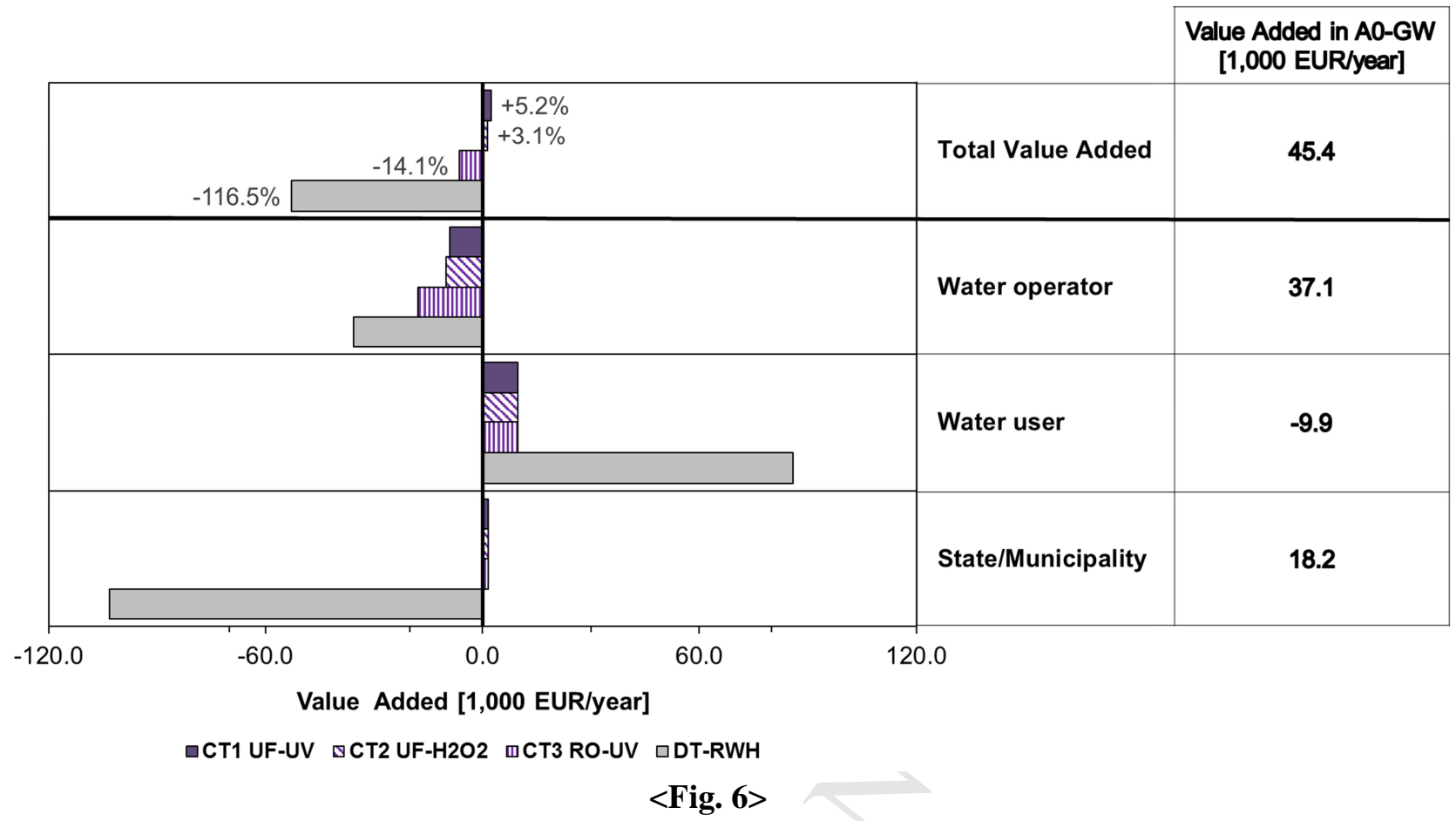

\subsection{Eco-efficiency}

Table 6. Normalised TVA and LCA impact categories in the range [0,1]. Alternatives performing better than the baseline marked in bold. TVA: total value added, CC: climate change, PM: particulate matter, E-TOX: ecotoxicity, RD-fossil: fossil resource depletion, RD-reserve: reserve base resource depletion, FD: Freshwater depletion.

\begin{tabular}{l|c|cccccc}
\hline & Economy & \multicolumn{7}{c}{ Environment } \\
\hline Alternative & TVA & CC & PM & E-TOX & RD-fossil & RD-reserve & FD \\
\hline A0-GW & 0.96 & 0.29 & 0.29 & 0.02 & 0.25 & 0.36 & 0.00 \\
\hline CT1 UF-UV & $\mathbf{1 . 0 0}$ & $\mathbf{1 . 0 0}$ & $\mathbf{0 . 6 8}$ & $\mathbf{1 . 0 0}$ & $\mathbf{1 . 0 0}$ & 0.05 & $\mathbf{1 . 0 0}$ \\
\hline CT2 UF-H2O2 & $\mathbf{0 . 9 8}$ & $\mathbf{0 . 8 4}$ & $\mathbf{0 . 6 4}$ & $\mathbf{1 . 0 0}$ & $\mathbf{0 . 9 6}$ & 0.00 & $\mathbf{1 . 0 0}$ \\
\hline CT3 RO-UV & 0.84 & 0.00 & 0.00 & $\mathbf{0 . 9 1}$ & 0.00 & 0.19 & $\mathbf{1 . 0 0}$ \\
\hline DT-RWH & 0.00 & 0.24 & $\mathbf{1 . 0 0}$ & 0.00 & 0.22 & $\mathbf{1 . 0 0}$ & $\mathbf{1 . 0 0}$ \\
\hline
\end{tabular}

The two centralised UF plants (CT1-CT2) showed overall improved eco-efficiency across most of the categories including TVA compared to A0-GW (Table 6). As such, they might be defined as the most eco-innovative alternatives compared to baseline (Table 6, Fig. F.1 in the Supporting Material). The only exception was seen for the reserve base resource category, where the UF plants produced higher impacts compared to A0-GW. The analysis therefore highlights the importance of 
the material choice for the water treatment infrastructure in CT1-CT2, which affects the impacts in the reserve base resource category and the final eco-efficiency definition for this category.

The analysis further established that a heavy rain- and stormwater treatment through a reverse osmosis unit did not provide additional value added and improved environmental performance. The only environmental benefits for CT3 RO-UV could be seen in the ecotoxicity and freshwater depletion, where these benefits could balance the decrease in TVA (trade-off position). The limiting parameter affecting the eco-efficiency performance of this alternative was certainly the electricity consumption.

Finally, the decentralised rainwater harvesting system (DT-RWH) performed better than A0-GW in three out of six LCA impact categories, but was the worst alternative in terms of TVA. The negative TVA was caused by a loss in income for the "municipality" although this alternative provided the highest value added for the water user.

The eco-efficiency definition showed how rain- and stormwater treated in centralised UF plants could improve the overall eco-efficiency of the urban water system in Nye from a societal economic perspective and an environmental perspective compared to conventional drinking water supply.

\subsection{Scenario analysis}

In case drinking water consumption during dry weather periods increases by $20 \%$, a decrease in TVA (up to $-10 \%)$ and a marked increase in freshwater depletion impacts $(+300 \%)$ would be expected in the alternatives with rainwater use (Table E.6 in the Supplementary Material).

Nonetheless, the two UF plants would be preferred in four out of six LCA impact categories and according to TVA.

If additional savings occurred, due to a further decrease in water hardness, the economic performance of the conventional drinking water system (A0-GW) would decrease (up to -20\%) and 
the LCA impacts increase by up to $+35 \%$. This would cause a larger positive difference between the eco-efficiency of the rainwater use alternatives and A0-GW, which would also make the RO plant more eco-innovative than A0-GW, thus showing higher TVA and reduced impacts than the baseline in five out six LCA impact categories.

If the effects of water hardness were excluded from the system boundaries, the TVA of conventional drinking water would increase by up to $+22 \%$, while LCA impacts would decrease by up to $-39 \%$. CT1-CT2 would then not be considered more eco-innovative than A0-GW, since they would provide lower TVA than the baseline alternative. The alternatives CT1-CT2 could still provide environmental benefits in four out of six LCA impact categories and might be therefore placed in a trade-off position according to those categories (Table E6 in the Supplementary Material). . The interpretation of the eco-efficiency therefore varied and a dominant pattern in the results was not present.

Therefore, our study suggests a deeper investigation of:

- The number of dry weather periods in Nye, in order to quantify drinking water interventions.

- Economic and environmental assessments of the effect of a water hardness lower than 145 $\mathrm{mg} / \mathrm{l} \mathrm{CaCO}_{3}$ at the end-user level.

Finally, in line with Godskesen et al. (2012), our study suggested that it is important to include the end use effect of water quality, in order to avoid misleading conclusions. 


\section{Conclusions}

We adapted the eco-efficiency assessment to analyse four alternatives for harvesting rain- and stormwater for non-potable use, in order to substitute a conventional groundwater-based drinking water supply: two centralised UF plants followed either by UV (CT1 UF-UV) or $\mathrm{H}_{2} \mathrm{O}_{2}$ disinfection (CT2 UF- $\mathrm{H}_{2} \mathrm{O}_{2}$ ), a centralised RO plant with UV (CT3 RO-UV) and a decentralised treatment solution involving the installation of $273 \mathrm{RWH}$ systems (DT-RWH). All of the alternatives involved stormwater collection through a system of basins and trenches.

Through the environmental assessment, we concluded:

- The business-as-usual (A0-GW) showed higher impacts than the alternatives with rain- and stormwater use in most of the impact categories, with freshwater depletion impacts being significantly higher $(+300 \%)$. The water hardness of the conventional drinking water system led to an increased demand in electricity and laundry detergents at the household level, which as a consequence affects electricity-related impact categories (climate change, fossil resource depletion) and reserve base resource depletion.

- In all of the alternatives, the discharge of runoff pollutants into the receiving water body dominated ecotoxicity impacts.

- Electricity use in the operation phase contributed markedly to climate change and fossil resource depletion impacts in all alternative scenarios. Alternatives treating rainwater through ultrafiltration (CT1-CT2) were the most electricity-efficient choices.

- Material demands for water treatment infrastructure, basins and trenches components played an important role in decreasing the potential environmental impacts of reserve base resource depletion.

Through the economic assessment, we concluded: 
487

- The study provided the first total value added (TVA) assessment of five alternatives for nonpotable water and stormwater management in a new urban development.

- The two ultrafiltration plants (CT1-CT2) were preferable from a societal economic perspective as a result of added value for the water user that offset the loss of value for the water operator.

- The private rainwater harvesting alternative had the highest value generation for the water user, due to reduced water fees and incentives for private rainwater harvesting, but it also provided the lowest TVA throughout the water chain.

In summary, the two ultrafiltration plants were found to have lower environmental impacts and generate value added compared to a conventional groundwater-based water supply, with the only exception being for reserve base resource depletion.

The combined environmental and economic assessment constituted important decision-making support for the planning of stormwater management in Nye. Our findings support the implementation of alternative non-potable water supply in the new urban development and provide a definition of the eco-efficiency for the five systems.

\section{Acknowledgements}

The authors would like to thank Aarhus Vand, and in particular Mariann Brun, for providing data for the case study, Carsten Fjordback from COWI and Søren Duch-Hennings from SilhorkoEurowater for providing additional data, Rasmus Frydendal from HPNow for the $\mathrm{H}_{2} \mathrm{O}_{2}$ disinfection technology, and Anders Damgaard for the support in EASETECH modelling.

\section{Supplementary material}

It contains a text file with Appendix A-D and F and a spreadsheet with Table E.1-E.6.

Declarations of interest: none. 


\section{References}

Aarhus Kommune, 2016a. Lokalplan nr. 1016. Nye - Første etape af ny by ved Elev. Aarhus Kommune.

Aarhus Kommune, 2016b. Vandforsyningsplan 2016-2023. Rent drikkevand til en kommune i vækst.

Aarhus Vand, Personal communication. Personal communication with Mariann Brun. Project Manager.

Amini, A., Kim, Y., Zhang, J., Boyer, T., Zhang, Q., 2015. Environmental and economic sustainability of ion exchange drinking water treatment for organics removal. J. Clean. Prod. 104, 413-421. doi:10.1016/j.jclepro.2015.05.056

Amores, M.J., Meneses, M., Pasqualino, J., Antón, A., Castells, F., 2013. Environmental assessment of urban water cycle on Mediterranean conditions by LCA approach. J. Clean. Prod. 43, 84-92. doi:10.1016/j.jclepro.2012.12.033

Angelis-Dimakis, A., Arampatzis, G., Assimacopoulos, D., 2016. Systemic eco-efficiency assessment of meso-level water use systems. J. Clean. Prod. 138, 195-207. doi:10.1016/j.jclepro.2016.02.136

Arampatzis, G., Angelis-Dimakis, A., Blind, M., Assimacopoulos, D., 2016. A web-based Toolbox to support the systemic eco-efficiency assessment in water use systems. J. Clean. Prod. 138, 181-194. doi:10.1016/j.jclepro.2016.02.065

Barjoveanu, G., Comandaru, I.M., Rodriguez-Garcia, G., Hospido, A., Teodosiu, C., 2014. Evaluation of water services system through LCA. A case study for Iasi City, Romania. Int. J. Life Cycle Assess. 19, 449-462. doi:10.1007/s11367-013-0635-8

Brudler, S., Arnbjerg-Nielsen, K., Hauschild, M.Z., Ammitsøe, C., Hénonin, J., Rygaard, M., unpublished-a. Integrating local emissions in life cycle assessment of urban water systems.

Brudler, S., Arnbjerg-Nielsen, K., Hauschild, M.Z., Rygaard, M., 2016. Life cycle assessment of stormwater management in the context of climate change adaptation. Water Res. 106, 394-404. doi:10.1016/j.watres.2016.10.024

Brudler, S., Rygaard, M., Arnbjerg-Nielsen, K., Hauschild, M.Z., Ammitsøe, C., Vezzaro, L., unpublished-b. Defining pollution levels for assessing environmental risks and impacts of urban stormwater discharges. (Submitted).

Bülow, I.G., Madsen, H., Linde, J.J., Arnbjerg-Nielsen, K., 2014. Skrift 30 - Opdaterede klimafaktorer og dimensionsgivende regnintensiteter (in English: Updated Climate Factors and Rain Intensities). 
Clavreul, J., Baumeister, H., Christensen, T.H., Damgaard, A., 2014. An environmental assessment system for environmental technologies. Environ. Model. Softw. 60, 18-30. doi:10.1016/j.envsoft.2014.06.007

Damgaard, Anders; Erikssen, Marie; Bassi , Susanna Andreasi; Sanchez, V.M., 2016. EASETECH User Manual. Kogens Lyngby.

DANVA, 2013. DANVA - Dansk Vand og Spildevandsforening. Vandforbrug [WWW Document]. URL http://old.danva.dk/Presse/Vandsektoren/Vandforbrug.aspx (accessed 1.11.17).

Danmarks Meteorologiske Institut, 2018. Vejrarkiv: DMI [WWW Document]. Danmarks Meteorol. Inst. URL https://www.dmi.dk/vejr/arkiver/vejrarkiv/\# (accessed 12.14.18).

Domènech, L., Saurí, D., 2011. A comparative appraisal of the use of rainwater harvesting in single and multi-family buildings of the Metropolitan Area of Barcelona (Spain): social experience, drinking water savings and economic costs. J. Clean. Prod. 19, 598-608. doi:10.1016/j.jclepro.2010.11.010

European Commission - Joint Research Centre - Institute for Environment and Sustainability, 2010. International Reference Life Cycle Data System (ILCD) Handbook - General guide for Life Cycle Assessment - Detailed guidance, International Reference Life Cycle Data System (ILCD) Handbook. Luxembourg. doi:10.2788/38479

Fang, L.L., Valverde-Pérez, B., Damgaard, A., Plósz, B.G., Rygaard, M., 2016. Life cycle assessment as development and decision support tool for wastewater resource recovery technology. Water Res. 88, 538-549. doi:10.1016/j.watres.2015.10.016

Fragkou, M.C., Vicent, T., Gabarrell, X., 2016. An ecosystemic approach for assessing the urban water self-sufficiency potential: lessons from the Mediterranean. Urban Water J. 13, 663-675. doi:10.1080/1573062X.2015.1024686

Gejl, R.N., Bjerg, P.L., Henriksen, H.J., Hauschild, M.Z., Rasmussen, J., Rygaard, M., 2018. Integrating groundwater stress in life-cycle assessments - An evaluation of water abstraction. J. Environ. Manage. 222, 112-121. doi:10.1016/J.JENVMAN.2018.05.058

Ghimire, S.R., Johnston, J.M., Ingwersen, W.W., Sojka, S., 2017. Life cycle assessment of a commercial rainwater harvesting system compared with a municipal water supply system. J. Clean. Prod. 151, 74-86. doi:10.1016/j.jclepro.2017.02.025

Gill, S.., Handley, J.., Ennos, A.., Pauleit, S., 2007. Adapting Cities for Climate Change: The Role of the Green Infrastructure. Built Environ. 33, 115-133. doi:10.2148/benv.33.1.115

Godskesen, B., Hauschild, M., Rygaard, M., Zambrano, K., Albrechtsen, H.-J., 2012. Life cycle assessment of central softening of very hard drinking water. J. Environ. Manage. 105, 83-89. doi:10.1016/j.jenvman.2012.03.030 
Godskesen, B., Hauschild, M., Rygaard, M., Zambrano, K., Albrechtsen, H.-J., 2013. Life-cycle and freshwater withdrawal impact assessment of water supply technologies. Water Res. 47, 2363-74. doi:10.1016/j.watres.2013.02.005

Gregersen, I.B., Arnbjerg-Nielsen, K., 2012. Decision strategies for handling the uncertainty of future extreme rainfall under the influence of climate change. Water Sci. Technol. 66, 284-291. doi:10.2166/wst.2012.173

Igos, E., Dalle, A., Tiruta-Barna, L., Benetto, E., Baudin, I., Mery, Y., 2014. Life Cycle Assessment of water treatment: what is the contribution of infrastructure and operation at unit process level? J. Clean. Prod. 65, 424-431. doi:10.1016/j.jclepro.2013.07.061

IDA Spildevandskomitéen, 2014. Skrift 30 - Opdaterede klimafaktorer og dimensionsgivende regnintensiteter.

ISO, 2012. Environmental management - Eco-efficiency assessment of product systems Principles, requirements and guidelines (ISO 14045:2012).

Jeong, H., Broesicke, O.A., Drew, B., Li, D., Crittenden, J.C., 2016. Life cycle assessment of low impact development technologies combined with conventional centralized water systems for the City of Atlanta, Georgia. Front. Environ. Sci. Eng. 10, 1. doi:10.1007/s11783-016-0851-0

Jeong, H., Minne, E., Crittenden, J.C., 2015. Life cycle assessment of the City of Atlanta, Georgia's centralized water system. Int. J. Life Cycle Assess. 20, 880-891. doi:10.1007/s11367-015-0874y

Kundzewicz, Z.W., Mata, L.J., Arnell, N.., Döll, P., Kabat, P., Jiménez, B., Miller, K.., Oki, T., Sen, Z., Shiklomanov, I.A., 2007. Freshwater resources and their management. Climate Change 2007: Impacts, Adaptation and Vulnerability. Contribution of Working Group II to the Fourth Assessment Report of the Intergovernmental Panel on Climate Change, M.L. Parry, O.F. Canziani, J.P. Palut.

Lam, K.L., Stokes-Draut, J.R., Horvath, A., Lane, J.L., Kenway, S.J., Lant, P.A., 2017. Life-cycle energy impacts for adapting an urban water supply system to droughts. Water Res. 127, 139149. doi:10.1016/J.WATRES.2017.10.016

Levidow, L., Lindgaard-Jørgensen, P., Nilsson, A., Skenhall, S.A., Assimacopoulos, D., 2016. Process eco-innovation: Assessing meso-level eco-efficiency in industrial water-service systems. J. Clean. Prod. 110, 54-65. doi:10.1016/j.jclepro.2014.12.086

Li, Y., Xiong, W., Zhang, W., Wang, C., Wang, P., 2016. Life cycle assessment of water supply alternatives in water-receiving areas of the South-to-North Water Diversion Project in China. Water Res. 89, 9-19. doi:10.1016/j.watres.2015.11.030 
611

612

613

614

615

616

617

618

619

620

621

622

623

624

625

626

627

628

629

630

631

632

633

634

635

636

637

638

639

640

641

642

Miljøstyrelsen, 2014. Handlingsplan for klimasikring af Danmark [WWW Document]. URL http://www.klimatilpasning.dk/kommuner/handlingsplan-for-klimasikring-af-danmark.aspx (accessed 3.19.17).

Nye [WWW Document], 2016. URL http://www.nye.dk/miljoe/ (accessed 3.18.17).

Opher, T., Friedler, E., 2016. Comparative LCA of decentralized wastewater treatment alternatives for non-potable urban reuse. J. Environ. Manage. 182, 464-476. doi:10.1016/j.jenvman.2016.07.080

Petit-Boix, A., Arahuetes, A., Josa, A., Rieradevall, J., Gabarrell, X., 2016. Are we preventing flood damage eco-efficiently? An integrated method applied to post-disaster emergency actions. Sci. Total Environ. 580, 873-881. doi:10.1016/j.scitotenv.2016.12.034

Petit-Boix, A., Sevigné-Itoiz, E., Rojas-Gutierrez, L.A., Barbassa, A.P., Josa, A., Rieradevall, J., Gabarrell, X., 2015. Environmental and economic assessment of a pilot stormwater infiltration system for flood prevention in Brazil. Ecol. Eng. 84, 194-201. doi:10.1016/j.ecoleng.2015.09.010

Ribarova, I., Stanchev, P., Dimova, G., Assimacopoulos, D., 2013. A First Iteration of an Ecoefficiency Assessment of Sofia's Urban Water System. Procedia Eng. 0, 0-0.

Rygaard, M., Arvin, E., Bath, A., Binning, P.J., 2011a. Designing water supplies: Optimizing drinking water composition for maximum economic benefit. Water Res. 45, 3712-3722. doi:10.1016/j.watres.2011.04.025

Rygaard, M., Binning, P.J., Albrechtsen, H.-J., 2011b. Increasing urban water self-sufficiency: New era, new challenges. J. Environ. Manage. 92, 185-194. doi:10.1016/j.jenvman.2010.09.009

Sørup, H.J.D., Arnbjerg-Nielsen, K., Mikkelsen, P.S., Rygaard, M., 2012. Quantitative potential for rainwater use. Kgs. Lyngby: DTU Environment.

Stanchev, P., Ribarova, I., 2016. Complexity, assumptions and solutions for eco-efficiency assessment of urban water systems. J. Clean. Prod. 138, 229-236. doi:10.1016/j.jclepro.2016.03.113

Tang, C., Albrechtsen, H., 2016. Vandkvalitetskrav for anvendelser af opsamlet regnvand i tøjvask, toiletskyl og brandslukning: Centralt sekundavandsanlæg i bydelen Nye, Aarhus. Kgs. Lyngby Technical University of Denmark.

Tarantini, M., Ferri, F., 2001. LCA of drinking and wastewater treatment systems of Bologna city: final results. In 4th IRCEW Conference, Inter-Regional Conference on Environment-Water Fortaleza, Brazil. 
643
Vieira, A.S., Beal, C.D., Ghisi, E., Stewart, R.A., Vieira, A.S., Beal, C.D., Ghisi, E., Stewart, R.A., 2014. Energy intensity of rainwater harvesting systems: A review. Reviews 34, 225-242. doi:10.1016/j.rser.2014.03.012

Wernet, G., Bauer, C., Steubing, B., Reinhard, J., Moreno-Ruiz, E., Weidema, B., 2016. The ecoinvent database version 3 (part I): overview and methodology. Int. J. Life Cycle Assess. 21, 1218-1230. doi:10.1007/s11367-016-1087-8

WHO, 2011. Hardness in Drinking-water Background document for development of WHO Guidelines for Drinking-water Quality [WWW Document]. URL http://www.who.int/water_sanitation_health/dwq/chemicals/hardness.pdf (accessed 4.9.17).

Wong, T.H.F., Allen, R., Beringer, J., Brown, R.R., Deletić, A., Fletcher, T.D., Gangadharan, L., Gernjak, W., Jakob, C., O’Loan, T., Reeder, M., Tapper, N., Walsh, C., 2012. Stormwater Management in a Water Sensitive City. Clayton, VIC, Australia. 
671

672

673

674

675

676

677

678

679

680

681

682

683

684

685

686

687

688

689

690

691

692

693

\section{Figure captions}

Fig. 1. Sub-division of the planning area for the Nye first phase. Basins A, B, C and D collect stormwater from four sub-catchments. Water from basins A, B and C eventually runs into basin D (Source: adapted from Aarhus Kommune (2016a)).

Fig. 2. System boundaries definition for the urban water system with an indication of economic actors along the water chain. The dotted grey squares indicate processes excluded from the assessment. SW: secondary water, DW: drinking water.

Fig. 3. Water flows in the business-as-usual alternative (A0-GW), the three alternatives with centralised stormwater treatment (CT1-CT3) and the private rainwater harvesting (DT-RWH).

Fig. 4. Percentage relative change from A0-GW, whose total normalised results are presented in the table on the right. Positive relative change means higher impacts than A0-GW, and negative relative change means lower impacts than A0-GW. FU was the yearly provision of $31,000 \mathrm{~m}^{3}$ of non-potable water. The absolute values of the impact categories in each of the alternatives is provided in Table E.4 in the Supplementary Material.

Fig. 5. Percentage contribution of the main system components to total impacts in the alternatives with rainwater and stormwater use. CC: climate change, PM: particulate matter, E-TOX: ecotoxicity, RD-fossil: fossil resource depletion, RD-reserve: reserve base resource depletion. Freshwater depletion impacts are not reported, since only groundwater abstraction affects the impacts.

Fig. 6. Absolute change in the total value added and the value added (VA) for each stakeholder compared to A0-GW. Absolute values for A0-GW are placed in the table on the right. Positive absolute change means higher TVA than A0-GW, and negative absolute change means lower TVA than A0-GW. 


\section{Highlights}

- Eco-efficiency evaluation of rainwater use for non-potable applications

- Comparison of 4 rainwater harvesting options versus conventional water system

- Economic and environmental impact assessment for the entire water chain

- Two ultrafiltration based plants performed better than conventional water system

- Eco-efficiency can support early planning phase of rainwater harvesting systems 